\title{
Analisis Faktor Kepatuhan Berobat Berdasarkan Skor MMAS-8 pada Pasien Diabetes Mellitus Tipe 2
}

\author{
Siti Julaiha \\ Jurusan Farmasi, Politeknik Kesehatan Tanjung Karang, Indonesia \\ Email: sitijulaiha@poltekkes-tjk.ac.id
}

\begin{abstract}
Analysis of Factors Associated with Medication Adherence Based on MMAS-8 Score to Type 2 Diabetes Mellitus patient. Diabetes mellitus is a chronic metabolic disease known as a deadly killer. Indonesia ranks 5th in the world in the number of people with Diabetes Mellitus in 2014. Poor medication adherence can increase microvascular and microvascular complications that cause damage to organs such as fat, heart, brain, and eyes. Patient adherence can be measured using a questionnaire 8- Morisky item Medication adherence Scale (MMAS-8). This instrument can be used to measure medication adherence in patients with chronic diseases such as hypertension, diabetes mellitus, tuberculosis, etc. This study aimed to analyze the factors associated with Medication Adherence Based On MMAS-8 Score to Type 2 Diabetes Mellitus Outpatient at Mardi Waluyo Hospital Metro in 2018. This research is an analytic observational study with a design cross-sectional study. The population of this study was type 2 DM outpatients who were treated at Mardi Waluyo Hospital Metro in 2018. The data collected were the results of research using the MMAS-8 questionnaire. Data were analyzed by using chi-square and multivariate logistic regression method. Result of this study showed that the patient who has income $<\operatorname{Rp} 2,100,000$ risk nonadherence 2,981 times higher than a patient who has an income of $\geq$ Rp.2,100,000. Patients with primary education risk nonadherence 2.724 times higher than patients with further education.
\end{abstract}

Keywords: MMAS-8, Patient adherence, Type-2 Diabetes Mellitus

\begin{abstract}
Abstrak: Analisis Faktor Kepatuhan Berobat Berdasarkan Skor MMAS-8 pada Pasien
Diabetes Mellitus Tipe 2. Diabetes Mellitus merupakan penyakit gangguan metabolik kronis yang dikenal sebagai sillent killer. Indonesia menempati urutan ke-5 terbesar di dunia dalam jumlah penderita Diabetes Mellitus pada tahun 2014. Ketidakpatuhan pasien terhadap rekomendasi terapi dapat meningkatkan risiko komplikasi mikrovaskular dan makrovaskular yang menyebabkan kerusakan organ seperti ginjal, jantung, otak, dan mata. Salah satu instrumen kepatuhan pengobatan yang dapat dipakai adalah MMAS-8 (Morisky Medication 8-item Adherence Scale) yaitu nilai kepatuhan mengkonsumsi obat dengan 8 skala pengukuran yang digunakan untuk mengukur kepatuhan minum obat pada penderita penyakit kronik yang membutuhkan terapi jangka panjang seperti hipertensi, diabetes mellitus, TBC, dll. Tujuan penelitian ini adalah untuk mengetahui faktor-faktor yang berhubungan dengan kepatuhan berobat pada pasien DM tipe 2 rawat jalan di RS Mardiwaluyo Kota Metro tahun 2018. Desain penelitian adalah observasi analitik dengan pendekatan cross sectional. Populasi penelitian ini adalah pasien DM tipe 2 yang berobat rawat jalan di RS Mardi Waluyo Kota Metro Tahun 2018. Data yang dikumpulkan merupakan hasil pengukuran kepatuhan dengan menggunakan kuesioner MMAS-8. Analisis data menggunakan uji chi square dan uji regresi logistik multivariat. Hasil penelitian menunjukkan pendapatan dan pendidikan merupakan faktor risiko terbesar bagi ketidakpatuhan berobat pada pasien diabetes mellitus tipe 2 di RS Mardi Waluyo Kota Metro. Pasien dengan pendapatan $<\mathrm{Rp}$ 2.100.000,- memiliki risiko tidak patuh sebesar 2,981 kali dibandingkan dengan pasien DM tipe 2 rawat jalan dengan pendapatan $\geq \operatorname{Rp} 2.100 .000$,-. Pasien dengan pendidikan dasar memiliki risiko tidak patuh sebesar 2,724 kali dibanding pasien dengan pendidikan lanjutan.
\end{abstract}

Kata kunci: MMAS-8, Kepatuhan berobat, Diabetes Mellitus tipe 2

\section{PENDAHULUAN}

Penyakit Diabetes Mellitus merupakan salah satu masalah kesehatan di masyarakat yang dewasa ini prevalensinya semakin meningkat. Diabetes Mellitus merupakan penyakit gangguan metabolik kronis yang dikenal sebagai sillent killer atau pembunuh manusia secara diam-diam. 
Diabetes Mellitus dikenal sebagai Mother of Disease yang merupakan induk penyakitpenyakit lain seperti penyakit kardiovaskuler, gagal ginjal, dan kebutaan (American Diabetes Association, 2017). WHO secara resmi merilis 10 penyakit penyebab kematian tertinggi di Indonesia, Diabetes Mellitus menempati urutan ketiga setelah penyakit stroke dan penyakit iskemia jantung (WHO, 2013). Selanjutnya pada Tahun 2017, prevalensi Diabetes Mellitus tercatat sebesar $6,7 \%$ dari total orang dewasa di Indonesia atau sekitar 10 juta kasus (IDF, 2017).

Diabetes Mellitus Tipe-2 merupakan diabetes yang paling sering dijumpai. Jumlah penderita DM tipe-2 tercatat sekitar 90\% dari total keseluruhan penderita diabetes di seluruh dunia (World Health Organization, 2013).

Diabetes Mellitus merupakan penyakit kronis kompleks yang membutuhkan perawatan medis jangka panjang dengan cara pengurangan risiko yang disebabkan oleh berbagai faktor seperti mengendalikan kadar glukosa dalam darah (American Diabetes Association, 2017). Penyakit Diabetes Mellitus seringkali tidak terdeteksi dan onset atau mulai terjadinya DM tujuh tahun sebelum diagnosis ditegakkan, sehingga morbiditas dan mortalitas dini terjadi pada kasus yang tidak terdeteksi ini (Soegondo, et al., 2009).

Pengobatan pada pasien Diabetes Mellitus (DM) bertujuan untuk mencegah komplikasi dan meningkatkan keberhasilan terapi. Keberhasilan pengobatan tidak hanya meliputi ketepatan diagnosa, ketepatan pemilihan obat, ketepatan pemilihan dosis, tetapi juga kepatuhan dalam berobat (Anna, 2011).

Salah satu indikator keberhasilan penatalaksanaan terapi yaitu kepatuhan pasien terhadap rekomendasi terapi. Ketidakpatuhan pasien terhadap rekomendasi terapi dapat meningkatkan risiko komplikasi mikrovaskular dan makrovaskular yang menyebabkan kerusakan organ seperti ginjal, jantung, otak, dan mata (Shams, Barakat, 2010). Sebaliknya, kepatuhan pasien Diabetes Mellitus terhadap terapi yang telah diindikasikan dan diresepkan oleh dokter akan memberikan efek terapeutik yang positif. Dalam kenyataannya, meskipun memerlukan tingkat kepatuhan pengobatan yang tinggi, masih banyak pasien yang memiliki tingkat kepatuhan rendah dalam menjalankan program manajemen pengobatan (Tombokan, 2015).

Kepatuhan merupakan kejadian multifaktor yang saling terkait yaitu faktor sosial dan ekonomi, faktor sistem kesehatan, faktor kondisi penyakit, faktor terapi dan faktor pasien. Oleh karena itu dalam menyelesaikan masalah tentang kepatuhan pasien tidak sepenuhnya terdapat pada pasien, namun juga dilakukan adanya pembenahan pada sistem kesehatan dan petugas pelayanan kesehatan (Perkeni, 2015). Salah satu instrumen kepatuhan pengobatan yang dapat dipakai adalah MMAS-8 (Morisky Medication 8item Adherence Scale) yaitu nilai kepatuhan mengkonsumsi obat dengan 8 skala pengukuran yang digunakan untuk mengukur kepatuhan minum obat pada penderita penyakit kronik yang membutuhkan terapi jangka panjang seperti hipertensi, diabetes mellitus, TBC, dll (Morisky, et al, 2008).

Prevalensi kepatuhan pasien pada terapi jangka panjang di negara-negara maju hanya berkisar 50\%, sedangkan di negara-negara berkembang prevalensinya lebih rendah (Wiffen, et al, 2015). Faktor yang mempengaruhi kepatuhan pasien dalam berobat antara lain jenis kelamin, umur, tingkat pendidikan, pekerjaan, pendapatan, dan status pernikahan, tersedianya asuransi kesehatan yang meringankan pasien dalam membayar biaya pengobatan, penyakit penyerta, lama pengobatan, jenis pengobatan, jumlah item obat, reaksi obat tidak dikehendaki/ROTD, penggunaan obat alternatif, dan edukasi (Suhadi, 2011; Wulandari, Andrajati, \& Supardi, 2015; Bagonza, Rutebemberwa, \& Bazeyo, 2015; Wiffen, et al., 2015).

Menurut penelitian Boyoh, et al., (2015), data yang didapat dari hasil penelitian hubungan pengetahuan dengan kepatuhan minum obat pada pasien Diabetes Mellitus Tipe-2 di Poliklinik Endokrin RSUP Prof.Dr. R. D. Kandou Manado yaitu lebih banyak yang tidak patuh sebesar $62.1 \%$.

Tujuan penelitian ini adalah untuk mengetahui faktor-faktor yang berhubungan dengan kepatuhan berobat dan faktor yang paling dominan beerhubungan dengan kepatuhan berobat pada pasien Diabetes Mellitus Tipe-2 Rawat Jalan di Rumah Sakit Mardi Waluyo Kota Metro Tahun 2018.

\section{METODE}

Penelitian ini merupakan penelitian observasi analitik dengan pendekatan cross sectional. Pengukuran terhadap variable independen dan dependen dilakukan sekali dalam waktu yang bersamaan. Variabel dependen dalam penelitian ini adalah kepatuhan berobat, sedangkan variabel independen meliputi jenis kelamin, umur, tingkat pendidikan, pekerjaan, pendapatan, status pernikahan, penyakit penyerta, lama pengobatan, jenis pengobatan, jumlah item 
obat, reaksi obat tidak dikehendaki/ROTD, interaksi obat, penggunaan obat alternatif, dan edukasi.

Kepatuhan berobat pasien Diabetes Mellitus (DM) Tipe-2 diukur dengan menggunakan score yang diperoleh dari hasil pengisian kuisioner MMAS-8 seperti yang terlihat pada table 1 . Pertanyaan dari no. 1 hingga 7 untuk "ya" bernilai 1 dan "tidak" bernilai 0 . Sedangkan pertanyaan pada no. 5 untuk jawaban "ya" bernilai 0 dan "tidak" bernilai 1. Pertanyaan pada no. 8 untuk jawaban "A" bernilai 0 dan jawaban "B-E" bernilai 1. Pasien dinyatakan patuh jika skor 0-2. Pasien dinyatakan tidak patuh jika skor $>2$.

Populasi dalam penelitian ini adalah seluruh pasien yang didiagnosis Diabetes Mellitus Tipe-2 Rawat Jalan di Rumah Sakit
Mardi Waluyo periode April-Juli tahun 2018 dengan jumlah sampel sebanyak 200 pasien.

Analisis data dilakukan secara univariat, bivariat, dan multivariat. Analisis univariat dilakukan untuk memperoleh gambaran karakteristik sosiodemografi dan karakteristik klinis pasien. Analisis bivariat dilakukan untuk melihat kekuatan hubungan antara faktor-faktor yang diteliti dengan kepatuhan berobat pada pasien DM tipe 2 Rawat Jalan di Rumah Sakit Mardi Waluyo Kota Metro. Analisis multivariat dilakukan untuk mengetahui faktor dominan yang berhubungan dengan kepatuhan berobat pada pasien.

Penelitian ini telah mendapatkan persetujuan etik penelitian (ecthical clearance) dari Komisi Etik Penelitian Kesehatan Politeknik Kesehatan Tanjung Karang Nomor 73/EC/KEP/TJK/IV/2018.

\section{HASIL}

Tabel 1. Distribusi Frekuensi Karakteristik Sosiodemografi Pasien DM Tipe 2

\begin{tabular}{|c|c|c|c|c|c|c|c|}
\hline \multirow{2}{*}{\multicolumn{2}{|c|}{ Karakteristik Sosiodemografi }} & \multicolumn{2}{|c|}{ Tidak Patuh } & \multicolumn{2}{|c|}{ Patuh } & \multicolumn{2}{|c|}{ Total } \\
\hline & & $n=84$ & $\%$ & $n=116$ & $\%$ & $n=200$ & $\%$ \\
\hline \multicolumn{8}{|c|}{ Jenis Kelamin } \\
\hline- & Perempuan & 69 & 48,9 & 72 & 51,1 & 141 & 100 \\
\hline- & Laki-laki & 15 & 25,4 & 44 & 74,6 & 59 & 100 \\
\hline \multicolumn{8}{|c|}{ Umur (dalam tahun) } \\
\hline- & Umur $\geq 60$ th & 41 & 43,6 & 53 & 56,4 & 94 & 100 \\
\hline- & Umur $<60$ th & 43 & 40,6 & 63 & 59,4 & 106 & 100 \\
\hline \multicolumn{8}{|c|}{ Pendidikan } \\
\hline- & SD & 37 & 59,7 & 25 & 40,3 & 62 & 100 \\
\hline- & SLTP & 24 & 66,7 & 12 & 33,3 & 36 & 100 \\
\hline- & SLTA & 13 & 19,6 & 41 & 80,4 & 54 & 100 \\
\hline & Perguruan tinggi & 9 & 19,6 & 37 & 80,4 & 46 & 100 \\
\hline \multicolumn{8}{|c|}{ Kategori : } \\
\hline- & Pendidikan dasar & 62 & 60.8 & 40 & 39,2 & 102 & 100 \\
\hline- & Pendidikan lanjutan & 22 & 22,4 & 76 & 77,6 & 98 & 100 \\
\hline \multicolumn{8}{|c|}{ Pekerjaan : } \\
\hline- & PNS & 6 & 23,1 & 20 & 76,9 & 26 & 100 \\
\hline- & PegawaiSwasta & 1 & 6,7 & 14 & 93,3 & 15 & 100 \\
\hline- & Wiraswasta & 16 & 42,1 & 22 & 57,9 & 38 & 100 \\
\hline- & Ibu RumahTangga & 48 & 62,3 & 29 & 37,7 & 77 & 100 \\
\hline- & Pensiunan & 4 & 14,3 & 24 & 85,7 & 28 & 100 \\
\hline- & Lainnya & 9 & 56,2 & 7 & 43,8 & 16 & 100 \\
\hline \multicolumn{8}{|c|}{ Kategori : } \\
\hline- & Tidak Bekerja & 53 & 51,0 & 51 & 49,0 & 104 & 100 \\
\hline- & Bekerja & 31 & 32,3 & 65 & 67,7 & 96 & 100 \\
\hline \multicolumn{8}{|c|}{ Pendapatan } \\
\hline- & $<\operatorname{Rp} 2.100 .000$ & 69 & 57,5 & 51 & 42,5 & 120 & 100 \\
\hline- & $>\operatorname{Rp} 2.100 .000$ & 15 & 18,8 & 65 & 81,2 & 80 & 100 \\
\hline \multicolumn{8}{|c|}{ Pernikahan } \\
\hline- & Tidak menikah & 13 & 54,2 & 11 & 45,8 & 24 & 100 \\
\hline- & Menikah & 71 & 40,3 & 105 & 59.7 & 176 & 100 \\
\hline
\end{tabular}

Jumlah pasien DM tipe 2 yang dijadikan sampel pada penelitian ini sebanyak 200 orang, yang terdiri dari 84 pasien tidak patuh dan 116 pasien patuh. Table 2 menunjukkan data karakteristik sosiodemografi pasien DM tipe 2 rawat jalan di RS Mardi Waluyo Kota Metro. 
Distribusi frekuensi sampel penelitian berdasarkan karakteristik sosiodemografi meliputi kelompok jenis kelamin, umur, tingkat pendidikan, pekerjaan, pendapatan, dan status pernikahan.

Sebagian besar pasien DM tipe 2 rawat jalan berjenis kelamin perempuan yaitu sebanyak 141 orang $(70,5 \%)$. Kelompok pasien tidak patuh dengan jenis kelamin perempuan sebesar $48,9 \%$. Sedangkan persentase pasien tidak patuh pada kelompok pasien dengan jenis kelamin laki-laki sebesar 25,4\%.

Pasien DM tipe 2 rawat jalan dengan umur kurang dari 60 tahun sebanyak 53\%. Kelompok pasien tidak patuh dengan umur $\geq 60$ tahun adalah sebesar $43,6 \%$. Sedangkan persentase pasien tidak patuh pada kelompok pasien dengan umur $<60$ tahun adalah sebesar 40,6\%.

Pasien DM tipe 2 rawat jalan memilki pendidikan SD sampai dengan SLTP (pendidikan dasar) yaitu sebanyak 102 orang $(51 \%)$ dan pendidikan SLTA sampai dengan perguruan tinggi (pendidikan lanjutan) sebanyak 98 orang (49\%). Kelompok pasien tidak patuh dengan pendidikan dasar sebesar 60,8\%. Sedangkan persentase pasien tidak patuh pada kelompok pasien dengan pendidikan lanjutan sebesar $22,4 \%$.

Pasien DM tipe 2 rawat jalan yang memiliki pekerjaan sebanyak 104 orang (52\%) dan yang tidak memiliki pekerjaan sebanyak 96 orang $(48 \%)$. Kelompok pasien tidak patuh yang tidak bekerja sebesar $51 \%$. Sedangkan persentase pasien tidak patuh pada kelompok pasien yang bekerja sebesar 32,3\%.

Sebagian besar pasien DM tipe 2 rawat jalan memiliki pendapatan kurang dari $\mathrm{Rp}$ 2.100.000,- yaitu sebanyak 120 orang (60\%). Sebagian besar pasien DM tipe 2 rawat jalan berstatus menikah yaitu sebanyak 176 orang $(88 \%)$.

Tabel 2. Karakteristik Klinis Pasien DM Tipe 2 Rawat Jalan

\begin{tabular}{|c|c|c|c|c|c|c|c|}
\hline & \multirow{2}{*}{ Karakteristik Klinis } & \multicolumn{2}{|c|}{ Tidak Patuh } & \multicolumn{2}{|c|}{ Patuh } & \multicolumn{2}{|c|}{ Total } \\
\hline & & $n=84$ & $\%$ & $n=116$ & $\%$ & $n=200$ & $\%$ \\
\hline \multicolumn{8}{|c|}{ Penyakit Penyerta } \\
\hline - & Ada & 77 & 41,8 & 107 & 58,2 & 184 & 100 \\
\hline- & Tidak Ada & 7 & 43,8 & 9 & 56,2 & 16 & 100 \\
\hline \multicolumn{8}{|c|}{ Lama Pengobatan1 } \\
\hline- & $>5$ tahun & 54 & 41,2 & 77 & 58,8 & 131 & 100 \\
\hline - & $\leq 5$ tahun & 30 & 43,5 & 39 & 56,5 & 69 & 100 \\
\hline \multicolumn{8}{|c|}{ Jenis Pengobatan } \\
\hline- & Oral + Injeksi & 27 & 39,1 & 42 & 60,9 & 69 & 100 \\
\hline - & Oral & 57 & 43,5 & 74 & 56,5 & 131 & 100 \\
\hline \multicolumn{8}{|c|}{ Jumlah Obat } \\
\hline- & $\geq 5$ & 58 & 41,1 & 83 & 58.9 & 141 & 100 \\
\hline- & $<5$ & 26 & 44,1 & 33 & 55.9 & 59 & 100 \\
\hline \multicolumn{8}{|c|}{ ROTD } \\
\hline- & Ada & 14 & 53,8 & 12 & 46,2 & 26 & 100 \\
\hline- & Tidak Ada & 70 & 40,2 & 104 & 59,8 & 174 & 100 \\
\hline \multicolumn{8}{|c|}{ Pengobatan Alternatif } \\
\hline - & Menggunakan & 32 & 43,8 & 41 & 56,2 & 73 & 100 \\
\hline- & Tidak Menggunakan & 52 & 40,9 & 75 & 59,1 & 127 & 100 \\
\hline \multicolumn{8}{|c|}{ Edukasi Pengobatan } \\
\hline- & Tidak diberikan & 47 & 39,8 & 71 & 60,2 & 118 & 100 \\
\hline- & Diberikan & 37 & 45,1 & 45 & 54,9 & 82 & 100 \\
\hline
\end{tabular}

Distribusi frekuensi sampel penelitian berdasarkan karakteristik klinis meliputi penyakit penyerta, lama pengobatan, jenis pengobatan, jumlah obat, ROTD, pengobatan alternatif, dan edukasi pengobatan pada pasien dapat dilihat pada tabel 3.

Sebagian besar pasien DM tipe 2 rawat jalan memiliki penyakit penyerta dengan jumlah 184 orang $(92 \%)$. Jenis penyakit penyerta yang diderita pasien meliputi gangguan kardiovaskuler, gangguan pernafasan, gangguan pencernaan, penyakit pada tulang, dan kulit, serta gangguan pada ginjal. Gangguan kardiovaskuler meruapakn jenis penyakit penyerta dengan distribusi frekuensi tertinggi $(49,46 \%)$.

Berdasarkan lama pengobatan, terlihat bahwa persentase kelompok pasien tidak patuh dengan lama pengobatan $>5$ tahun sebesar $41,2 \%$. Sedangkan persentase pasien tidak patuh pada kelompok pasien dengan lama pengobatan $\leq 5$ tahun sebesar $43,5 \%$.

Berdasarkan jenis pengobatan, terlihat bahwa persentase kelompok pasien tidak patuh dengan jenis pengobatan oral+injeksi adalah sebesar $39,1 \%$. Sedangkan persentase pasien 
tidak patuh pada kelompok pasien dengan jenis pengobatan oral adalah sebesar $43,5 \%$.

Berdasarkan jumlah obat, terlihat bahwa persentase kelompok pasien tidak patuh dengan jumlah obat $\geq 5$ obat adalah sebesar $41,1 \%$. Sedangkan persentase pasien tidak patuh pada kelompok pasien dengan jumlah obat $<5$ obat adalah sebesar $44,1 \%$.

Tabel 3. Hubungan antara Karakteristik Sosiodemografi dan Karakteristik Klinis Pasien dengan Kepatuhan Berobat pada Pasien Diabetes MellitusTipe 2 Rawat Jalan

\begin{tabular}{|c|c|c|c|c|c|c|c|}
\hline \multirow{2}{*}{ Variabel Penelitian } & \multicolumn{2}{|c|}{ Tidak Patuh } & \multicolumn{2}{|c|}{ Patuh } & \multirow{2}{*}{$\begin{array}{c}p- \\
\text { value }\end{array}$} & \multirow{2}{*}{ OR } & \multirow{2}{*}{$95 \% \mathrm{CI}$} \\
\hline & $n=84$ & $\%$ & $\mathrm{n}=116$ & $\%$ & & & \\
\hline \multicolumn{8}{|l|}{ Jenis Kelamin } \\
\hline - Perempuan & 69 & 48,9 & 72 & 51,1 & \multirow{2}{*}{0,004} & \multirow{2}{*}{2,811} & \multirow{2}{*}{$1,435-5,508$} \\
\hline - Laki-laki & 15 & 25,4 & 44 & 74,6 & & & \\
\hline \multicolumn{8}{|l|}{ Umur } \\
\hline - Umur $\geq 60$ th & 41 & 43,6 & 53 & 56,4 & \multirow[b]{2}{*}{0,770} & \multirow[b]{2}{*}{1,133} & \multirow{2}{*}{$0,646-1,989$} \\
\hline - Umur $<60$ th & 43 & 40,6 & 63 & 59,4 & & & \\
\hline \multicolumn{8}{|l|}{ Tingkat Pendidikan } \\
\hline - Pendidikan Dasar & 62 & 60,8 & 40 & 39,2 & \multirow{2}{*}{0.000} & \multirow{2}{*}{5,355} & \multirow{2}{*}{$2.883-9,944$} \\
\hline - $\quad$ Pendidikan Lanjutan & 22 & 22,4 & 76 & 77,6 & & & \\
\hline \multicolumn{8}{|l|}{ Pekerjaan } \\
\hline _ Tidak & 53 & 51,0 & 51 & 49,0 & \multirow{2}{*}{0,011} & \multirow{2}{*}{2,179} & \multirow{2}{*}{$1.226-3,873$} \\
\hline - Bekerja & 31 & 32,3 & 65 & 67,7 & & & \\
\hline \multicolumn{8}{|l|}{ Pendapatan } \\
\hline$-\quad<\operatorname{Rp} 2.100 .000$ & 69 & 57,5 & 51 & 42,5 & \multirow{2}{*}{0,000} & \multirow{2}{*}{5,863} & \\
\hline$-\quad>\operatorname{Rp} 2.100 .000$ & 15 & 18,8 & 65 & 81,2 & & & $3,006-11,434$ \\
\hline Setatus Pernikahan & & & & & & & \\
\hline - Tidak Menikah & 13 & 54,2 & 11 & 45,8 & 0286 & 1748 & 07414120 \\
\hline - Menikah & 71 & 40,3 & 105 & 59,7 & 0,280 & 1,148 & $0,741-4,120$ \\
\hline Penyakit Penyerta & & & & & & & \\
\hline - Ada & 77 & 41,8 & 107 & 58,2 & 1000 & 0025 & $0330-502$ \\
\hline - $\quad$ Tidak Ada & 7 & 43,8 & 9 & 56,2 & 1,000 & $0,92 J$ & 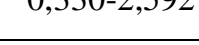 \\
\hline Lama Pengobatan 1 & & & & & & & \\
\hline$-\quad \geq 5$ tahun & 54 & 41,2 & 77 & 58,8 & 0.075 & 0012 & $05061<4$ \\
\hline$-<5$ tahun & 30 & 43,5 & 39 & 56,5 & $0,8 / 5$ & 0,912 & $0,506-1,644$ \\
\hline JenisPengobatan & & & & & & & \\
\hline - Oral + Injeksi & 27 & 39,1 & 42 & 60,9 & & & \\
\hline - Oral & 57 & 43,5 & 74 & 56,5 & 0,656 & 0,835 & $0,461-1,512$ \\
\hline Jumlah Obat & & & & & & & \\
\hline$-\quad \geq 5$ & 58 & 41,1 & 83 & 58,9 & & & $0480-1638$ \\
\hline$-<5$ & 26 & 44,1 & 33 & 55,9 & 0,821 & 0,881 & $0,480-1,638$ \\
\hline ROTD & & & & & & & \\
\hline - Ada & 14 & 53,8 & 12 & 46,2 & 0272 & 1733 & $0757-3960$ \\
\hline - $\quad$ Tidak Ada & 70 & 40,2 & 104 & 59,8 & $0,2 / 2$ & 1,133 & $0, / 3 /-5,909$ \\
\hline Penggunaan Obat Alternatif & & & & & & & \\
\hline - Menggunakan & 32 & 43,8 & 41 & 56,2 & 0803 & 1126 & $0.629-2.015$ \\
\hline - $\quad$ Tidak Menggunakan & 52 & 40,9 & 75 & 59,1 & 0,00J & 1,120 & $0,029-2,011$ \\
\hline Edukasi Pengobatan & & & & & & & \\
\hline - $\quad$ Tidak Diberikan & 47 & 39,8 & 71 & 60,2 & 10 & 05 & 124 \\
\hline Diberikan & 37 & 45,1 & 45 & 54,9 & 0,348 & 0,805 & $0,453-1,4 \angle 4$ \\
\hline
\end{tabular}

Berdasarkan ROTD, terlihat bahwa persentase kelompok pasien tidak patuh yang mengalami ROTD adalah sebesar 53,8\%. Sedangkan persentase pasien tidak patuh pada kelompok pasien yang tidak mengalami ROTD adalah sebesar $40,2 \%$. ROTD yang dialami pasien meliputi mual, kembung, sesak napas, pusing, dan lemas. Berdasarkan Pengobatan alternatif, terlihat bahwa persentase kelompok pasien tidak patuh yang menggunakan obat alternatif adalah sebesar 43,8\%. Sedangkan persentase pasien tidak patuh pada kelompok pasien yang tidak menggunakan obat alternatif adalah sebesar $40,9 \%$.

Berdasarkan edukasi pengobatan yang diterima pasien, terlihat bahwa persentase kelompok pasien tidak patuh yang tidak diberikan edukasi pengobatan adalah sebesar $39,8 \%$. Sedangkan persentase pasien tidak patuh pada kelompok pasien yang diberikan edukasi pengobatan adalah sebesar $45,1 \%$. 
Untuk mengetahui hubungan karakteristik sosiodemografi dan karakteristik klinis pasien dengan kepatuhan berobat pada pasien diabetes mellitus tipe 2 rawat jalan di RS Mardi Waluyo Kota Metro, dilakukan analisis bivariat dengan uji chi square seperti yang terlihat pada table 4 .
Hasil analisis bivariat pada table 4 menunjukkan ada empat variabel yang memiliki hubungan $(p<0,05)$ dengan kepatuhan berobat pada pasien DM tipe 2 rawat jalan di RS Mardi Waluyo Kota Metro. Variable tersebut adalah jenis kelamin, tingkat pendidikan, pekerjaan, dan pendapatan.

Tabel 5. Analisis Multivariat Faktor Dominan yang Berhubungan dengan Kepatuhan Berobat pada Pasien Diabetes Mellitus Tipe 2 Rawat Jalan

\begin{tabular}{|c|c|c|c|c|c|c|c|}
\hline & & B & Wald & Sig. & OR & 95.0\% C.I.for & $\mathbf{X P}(\mathbf{B})$ \\
\hline & & & & & & Lower & Upper \\
\hline Step $1^{a}$ & JenisKelamin 1 & .617 & 2.123 & .145 & 1.854 & .808 & 4.252 \\
\hline & Pendidikan 1 & .979 & 5.527 & .019 & 2.662 & 1.177 & 6.021 \\
\hline & Pekerjaan & -.144 & .136 & .712 & .866 & .404 & 1.858 \\
\hline & Pendapatan & 1.019 & 5.076 & .024 & 2.770 & 1.142 & 6.720 \\
\hline & Constant & -.578 & 6.201 & .013 & .561 & & \\
\hline Step $2^{a}$ & Jenis Kelamin 1 & .548 & 2.099 & .147 & 1.730 & .824 & 3.632 \\
\hline & Pendidikan 1 & .957 & 5.391 & .020 & 2.603 & 1.161 & 5.839 \\
\hline & Pendapatan & .990 & 4.941 & .026 & 2.691 & 1.124 & 6.439 \\
\hline & Constant & -.608 & 7.759 & .005 & .545 & & \\
\hline Step $3^{a}$ & Pendidikan 1 & 1.002 & 6.080 & .014 & 2.724 & 1.228 & 6.042 \\
\hline & Pendapatan & 1.092 & 6.273 & .012 & 2.981 & 1.268 & 7.007 \\
\hline & Constant & -.516 & 6.213 & .013 & .597 & & \\
\hline
\end{tabular}

Untuk mengetahui faktor dominan yang berhubungan dengan kepatuhan berobat pada pasien DM tipe 2 rawat jalan di RS Mardi Waluyo Kota Metro, dilakukan analisis multivariate regresi logistik ganda dengan metode stepwise backward (Likelihood Ratio).

Tabel 5 menunjukkan bahwa pasien DM Tipe 2 Rawat jalan dengan pendidikan dasar memiliki risiko tidak patuh sebesar 2,724 kali dibanding dengan pasien DM Tipe 2 Rawat jalan dengan pendidikan lanjutan. Selanjutnya, hasil analisis multivariate ini juga menunjukkan bahwa pasien dengan pendapatan $<\mathrm{Rp} 2.100 .000,-$ memiliki risiko tidak patuh sebesar 2,981 kali dibandingkan dengan pasien DM tipe 2 rawat jalan dengan pendapatan $\geq \operatorname{Rp} 2.100 .000$.

\section{PEMBAHASAN}

Hubungan antara Jenis Kelamin dengan
Kepatuhan Berobat

Pada penelitian ini didapatkan jumlah pasien perempuan lebih banyak dibandingkan laki-laki dikarenakan rata-rata ibu yang datang ke poli penyakit dalam untuk mengontrol adalah ibu rumah tangga. Hasil penelitian ini sejalan dengan penelitian yang dilakukan oleh Santhanakrishnan et al (2014) yang menunjukkan bahwa mayoritas pasien penderita DM 2 adalah perempuan (80\%).

Analisis hubungan kedua variabel didapatkan OR 2,811 (95\% CI 1,435-5,508), dan nilai $p$-value $=0,004$, artinya pasien diabetes mellitus tipe 2 berjenis kelamin perempuan berisiko sebesar 2,811 kali untuk tidak patuh dibandingkan dengan pasien diabetes mellitus tipe 2 berjenis kelamin laki-laki dan secara statistik bermakna. Hasil penelitian ini menunjukkan bahwa terdapat hubungan yang signifikan antara jenis kelamin dengan kepatuhan berobat pada pasien diabtese melitus tipe 2 rawat jalan di RS Mardi Waluyo Kota Metro.

Hasil penelitian ini sejalan dengan penelitian yg dilakukan Srikartika et al (2016) yang menyatakan bahwa terdapat hubungan yang signifikan $(p$-value $=0,011)$ antara jenis kelamin dan kepatuhan penggunaan obat pada pasien diabetes tipe 2, di mana pasien wanita lebih berisiko untuk tidak patuh sebesar 4,8 kali dibandingkan pasien laki-laki. responden wanita mengaku memiliki aktivitas yang padat sehingga membuatnya lupa minum obat dan terlambat menebus obat. Selain itu menurut literatur yang menghubungkan pengetahuan terhadap sikap berobat pasien DM menyatakan bahwa pasien pria memiliki sikap yang baik dibandingkan pasien perempuan dan pasien pria cenderung 
lebih peduli terhadap penyakitnya sehingga membuat pasien pria lebih rajin berolahraga, mengatur pola diet, serta lebih teratur minum obat (Romadona, 2011).

\section{Hubungan antara Umur dengan Kepatuhan Berobat}

Analisis hubungan umur dengan kepatuhan berobat didapatkan nilai $p$-value $=0,770$. Hasil penelitian ini menunjukkan bahwa tidak terdapat hubungan yang signifikan antara umur dengan kepatuhan berobat pada pasien diabetes mellitus tipe 2 rawat jalan di RS Mardi Waluyo Kota Metro.

Hasil penelitian ini sejalan dengan penelitian Elsous et al (2017) yang menunjukkan bahwa pasien DM tipe 2 dengan usia lebih 60 tahun tidak memiliki hubungan yang signifikan dengan kepatuhan ( $p$-value $=0,110)$. Demikian pula hasil penelitian Srikartika et al (2016) menunjukkan hasil yang sama, di mana pasien dengan usia $>65$ tahun tidak memiliki hubungan yang signifikan $(p$-value $=0,274)$ dengan kepatuhan berobat. Demikian dengan hasil penelitian Bgoza et al (2015) yang menujukkan bahwa tidak terdapat hubungan yang signifikan antara umur dengan kepatuhan berobat pasien diabetes.

\section{Hubungan antara Tingkat Pendidikan dengan Kepatuhan Berobat}

Analisis hubungan Tingkat pendidikan dengan kepatuhan berobat didapatkan OR 5,355 (95\% CI 2,883-9,944), dan nilai $p=0,000$, artinya pasien diabetes mellitus tipe 2 dengan pendidikan dasar berisiko sebesar 5,355 kali untuk tidak patuh dibandingkan dengan pasien diabetes mellitus tipe 2 dengan pendidikan lanjutan dan secara statistik bermakna. Hasil penelitian ini menunjukkan bahwa terdapat hubungan yang signifikan antara tingkat pendidikan dengan kepatuhan berobat pada pasien diabetes mellitus tipe 2 rawat jalan di RS Mardi Waluyo Kota Metro. Dari hasil wawancara didapatkan bahwa pasien berhenti meminum obat diabetes jika merasa kondisi kesehatan lebih baik atau lebih buruk. Selain itu, pasien seringkali lupa meminum obat dan membawa obat saat berpergian. Hal ini menunjukkan kurangnya pengetahuan pasien terkait pentingnya menggunakan obat diabetes secara teratur berdasarkan regimen terapi yang diberikan.

Hasil penelitian ini sejalan dengan hasil penelitian yang dilakukan oleh Serap \& Bayram (2015) menunjukkan bahwa terdapat hubungan yang signifikan $(p$-value $=0,014) \quad$ antara pendidikan dengan kepatuhan berobat pada pasien diabetes mellitus. Demikian pula dnegan penelitian Kassahun et al (2016) yang menunjukkan bahwa terdapat hubungan yang signifikan antara tingkat pendidikan pasien dengan kepatuhan berobat ( $p$-value $=0,003)$.

Hal ini berarti semakin rendah tingkat pendidikan maka semakin tidak patuh penderita untuk berobat karena rendahnya pendidikan seseorang sangat mempengaruhi daya serap seseorang dalam menerima informasi sehingga dapat mempengaruhi tingkat pemahaman tentang penyakit diabetes mellitus cara pengobatan, dan bahaya akibat minum obat tidak teratur.

Pendidikan merupakan hal yang sangat penting karena pendidikan mempengaruhi pola piker sesorang dalam pengambilan keputusan tertentu. Boswort \& Haident (2010) menyatakan bahwa pendidikan adalah salah satu faktor dari individu yang mempengaruhi kepatuhannya dalam menjalankan pengobatan. Menurut Boyoh et al (2015), pengetahuan sesorang dapat mempengaruhi kepatuhan untuk berobat karena semakin tinggi pendidikan seseorang maka semakin mudah untuh menerima suatu informasi.

Penelitian Srikartika et al (2016) menunjukkan bahwa Pasien mengaku tidak merasa khawatir jika terlambat menebus obat dan beberapa hari tanpa obat akan berakibat pada kesehatannya. Hal ini terkait dengan kurangnya pengetahuan pasien mengenai bahaya dan pentingnya pengobatan penyakit diabetes.

Kurangnya pengetahuan dan tindak lanjut pengobatan merupakan faktor terbesar yang berpengaruh terhadap kontrol gula darah pada pasien diabetes mellitus dan menyebabkan terapi diabetes menjadi suboptimal. Hal ini dapat menyebabkan tingginya angka rawat inap bagi pasien diabetes mellitus (Kassahun et al, 2016).

\section{Hubungan antara Pekerjaan dan Pendapatan dengan Kepatuhan Berobat}

Analisis hubungan pendapatan dengan kepatuhan berobat didapatkan OR 5,863 (95\% CI $3,006-11,434)$, dan nilai $p$-value $=0,000$, artinya pasien diabetes mellitus tipe 2 dengan pendapatan kurang dari Rp.2.100.000,- berisiko sebesar 5,863 kali untuk tidak patuh dibandingkan dengan pasien diabetes mellitus tipe 2 dengan pendapatan lebih dari Rp.2.100.000,- dan secara statistik bermakna. Hasil penelitian ini menunjukkan bahwa terdapat hubungan yang signifikan antara pendapatan dengan kepatuhan berobat pada pasien diabetes 
mellitus tipe 2 rawat jalan di RS Mardi Waluyo Kota Metro.

Analisis hubungan pekerjaan dengan kepatuhan berobat didapatkan OR 2,179 (95\% CI $1,226-3,873)$, dan nilai $p$-value $=0,011$, artinya pasien diabetes mellitus tipe 2 tidak bekerja berisiko sebesar 2,179 kali untuk tidak patuh dibandingkan dengan pasien diabetes mellitus tipe 2 yang bekerja dan secara statistik bermakna. Hasil penelitian ini menunjukkan bahwa terdapat hubungan yang signifikan antara pekerjaan dengan kepatuhan berobat pada pasien diabetes mellitus tipe 2 rawat jalan di RS Mardi Waluyo Kota Metro.

Pekerjaan dan pendapatan berkaitan dengan penghasilan yang diperoleh pasien. Berdasarkan hasil wawancara terhadap pasien, didapatkan informasi bahwa pasien mengalami kendala terkait biaya transportasi yang harus dikeluarkan saat perjalanan menuju rumah sakit. Hal ini mengakibatkan pasien terlambat mendapatkan obat. Dengan demikian, terdapat suatu kondisi pasien tidak meminum obat. Hal ini tentu berpengaruh terhadap kontrol kadar gula darah pasien.

Hasil penelitian ini sejalan dengan penelitian Bagonza et al (2015) dan Kassahun et al (2016) yang menunjukkan bahwa terdapat hubungan yang signifikan antara biaya berobat dengan kepatuhan berobat pasien diabetes di Negara berkembang. Biaya obat yang mahal dan biaya transport menuju sarana kesehatan dapat berpengaruh secara signifikan terhadap kepatuhan pasien, di mana faktor biaya dapat memberikan pengaruh yang negatif terhadap kepatuhan pasien dalam menjalankan terapinya.

\section{Hubungan antara Status Pernikahan dengan Kepatuhan Berobat}

Analisis hubungan status pernikahan dengan kepatuhan berobat didapatkan nilai $p$ value $=0,286$. Hasil penelitian ini menunjukkan bahwa tidak terdapat hubungan yang signifikan antara status pernikahan dengan kepatuhan berobat pada pasien diabetes mellitus tipe 2 rawat jalan di RS Mardi Waluyo Kota Metro.

Hasil penelitian ini sejalan dengan penelitian Bagonza et al (2015) yang menunjukkan bahwa tidak terdapat hubungan yang signifikan antara status pernikahan dengan kepatuhan berobat pasien. Demikian pula dengan hasil penelitian Elsous et al (2017) yang menunjukkan bahwa tidak terdapat hubungan yang signifikan ( $p$-value $=0,943)$ antara status pernikahan dengan kepatuhan berobat.
Hasil penelitian lainnya menyebutkan bahwa terdapat hubungan yang signifikan antara dukungan keluarga dengan keparuhan berobat pasien. Di mana dukungan secara emosional dari orang terdekat dapat memperbaiki tingkat kepatuhan pasien (Hannan, 2013).

\section{Hubungan antara Penyakit Penyerta dengan Kepatuhan Berobat}

Analisis hubungan penyakit penyerta dengan kepatuhan berobat didapatkan nilai $p$ value $=1,000$. Hasil penelitian ini menunjukkan bahwa tidak terdapat hubungan yang signifikan antara penyakit penyerta dengan kepatuhan berobat pada pasien diabetes mellitus tipe 2 rawat jalan di RS Mardi Waluyo Kota Metro.

Hail penelitian ini sejalan dengan penelitian Elsous et al (2017) yang menyatakan bahwa tidak terdapat hubungan yang signifikan antara penyakit penyerta dengan kepatuhan berobat pasien. Dalam penelitiannnya, Elsous et al (2017) meneliti hubungan natra beberapa penyakit penyerta yang seringkali timbul pada pasien diabetes mellitus anatar lain CVD, hipertensi, retinopati, neuropati dan nefrropati dengan kepatuhan berobat dengan pasien diabetes mellitus. Hasil penelitiannya menunjukkan bahwa tidak terdapat hubungan yang signifikan antara kelima penyakit tersebut dengan kepatuhan berobat pasien.

\section{Hubungan antara Lama Pengobatan dengan Kepatuhan Berobat}

Analisis hubungan lama pengobatan dengan kepatuhan berobat didapatkan nilai $p$ value $=0,875$. Hasil penelitian ini menunjukkan bahwa tidak terdapat hubungan yang signifikan antara lama pengobatan dengan kepatuhan berobat pada pasien diabetes mellitus tipe 2 rawat jalan di RS Mardi Waluyo Kota Metro.

Hasil penelitian ini sejalan dengan penelitian yang dilakukan oleh Elsous et al (2017) yang menunjukkan bahwa tidak terdapat hubungan yang bermakna antara lama pengobatan dengan kepatuhan berobat pasien ( $p$ value $=0,383$ ), di mana kepatuhan pasien dengan pengobatan lebih dari lima tahun tidak jauh berbeda dengan kepatuhan pasien dengan lama pengobatan kurang dari lima tahun.

Akan tetapi, hasil penelitian ini berbeda dengan peneltian Bagonza et al (2015) yang menyatakan bahwa terdapat hubungan yang signifikan antara lama berobat dengan kepatuhan berobat pasien diabetes, di mana pasien dengan lama pengobatan kurang dari tiga tahun 
cenderung tidak patuh ( $p$-value $=0,001)$ dibandingkan dengan pasien yang lama pengobatannya lebih dari tiga tahun. Menurut Bgonza et al (2015) pasien dengan pengobatan diabetes yang telah berlangsung lama, memiliki hubungan yang baik dengan petugas kesehatan dan mereka sudah lebih memahami regimen pengoabtan terkait diabetes yang diderita sehingga hal ini dapat memotivasi mereka untuk lebih patuh dalam menjalani terapi pengobatan diabetes.

Pasien dengan pengobatan lebih lama cenderung untuk patuh dibandingkan dengan pasien yang baru berobat. Hal ini terkait dengan komplikasi penyakit yang diderita pasien diabetes mellitus setelah sekian lama pengobatan. Pasien dengan komplikasi penyakit cenderung untuk peduli dengan penyakitnya sehingga pasien lebih patuh dalam menjalankan terapi pengobatan (Elsous et al, 2017).

Perbedaan hasil penelitian ini kemungkinan disebabkan karena jumlah sampel yang lebih kecil dibandingkan penelitian sebelumnya. Tetapi jika dilihat dari persentase kepatuhan pasien, terlihat bahwa persentase pasien patuh dengan lama pengobatan lebih dari 5 tahun $(58,8 \%)$ lebih besar dibandingkan dengan persentase pasien yang patuh dengan lama pengobatan kurang dari lima tahun $(56,5 \%)$.

\section{Hubungan antara Jenis Pengobatan dengan Kepatuhan Berobat}

Analisis hubungan jenis pengobatan dengan kepatuhan berobat didapatkan nilai $p$ value $=0,656$. Hasil penelitian ini menunjukkan bahwa tidak terdapat hubungan yang signifikan antara jenis pengobatan dengan kepatuhan berobat pada pasien diabetes mellitus tipe 2 rawat jalan di RS Mardi Waluyo Kota Metro.

Penelitian ini sejalan dengan penelitian yang dilakukan oleh Bagonza et al (2015) di Uganda yang menunjukkan bahwa tidak terdapat hubungan yang signifikan antara jenis pengobatan dengan kepatuhan berobat pada pasien diabetes mellitus. Hasil penelitian Bagonza et al (2015) menunjukkan bahwa tidak terdapat hubungan yang signifikan ( $p$ value $=0,903$ ) antara penggunaan obat oral dan injeksi dengan kepatuhan berobat pasien diabetes.

Demikian pula dengan penelitian yang dilakukan oleh Elsous (2017) yang menyatakan tidak terdapat hubungan yang bermakna ( $p$ value $=0,835$ ) antara penggunaan obat oral dan injeksi dengan kepatuhan berobat pasien diabetes.

\section{Hubungan antara Jumlah Obat dengan Kepatuhan Berobat}

Analisis hubungan jumlah obat dengan kepatuhan berobat didapatkan nilai $p$ value $=0,821$. Hasil penelitian ini menunjukkan bahwa tidak terdapat hubungan yang signifikan antara jumlah obat dengan kepatuhan berobat pada pasien diabetes mellitus tipe 2 rawat jalan di RS Mardi Waluyo Kota Metro.

Hasil penelitian ini sejalan dengan hasil penelitian Fatmawati (2017) yang menunjukkan hasil analisis multivariat bahwa tidak terdapat hubungan yang signifikan antara jumlah obat yang digunakan pasien dengan kepatuhan berobat pasien diabetes mellitus.

\section{Hubungan antara ROTD dengan Kepatuhan Berobat}

Hasil penelitian ini menunjukkan bahwa tidak terdapat hubungan yang signifikan secara statistic antara ROTD yang dirasakan pasien dengan kepatuhan berobat ( $p$-value $=0,272)$. Jika dilihat dari distribusi frekuensi kepatuhan pasien berdasarkan ROTD, terlihat bahwa persentase pasien yang tidak patuh yang mengalami ROTD lebih besar $(53,8 \%)$ dibandingkan dengan persentase pasien yang tidak patuh yang tidak mengalami ROTD $(40,2 \%)$.

Dari hasil wawancara pada penelitian ini didapatkan hasil bahwa salah satu penyebab ketidakpatuhan pasien dalam berobat adalah pasien memilih untuk berhenti meminum obat karena merasa bahwa kondisi lebih buruk. Salah satu faktor yang mendorong hal ini adalah reaksi obat yang tidak dikehendaki (ROTD) terkait obat diabetes. Di mana pasien merasa mual, pusing, lemas, dan perasaan sesak di dada setelah meminum obat diabetes.

Hasil penelitian Putra (2013) menunjukkan bahwa obat antidiabetes yang diduga menjadi penyebab timbulnya ROTD adalah insulin humulin 20/10, glibenklamid, dan metformin. Manifestasi yang ditimbulkan diantaranya rasa mual, muntah, kesemutan, dan lemas.

Perasaan bahwa kondisi penyakit lebih buruk pada pasien diabetes menjadi faktor penghalang bagi kepatuhan pasien dalam menjalankan terapi. Hal ini mendorong pentingnya untuk membangun kepercayaan pasien melalui edukasi terhadap pasien terkait keparahan penyakit diabetes, keuntungan terkait terapi pengobatan, dan faktor-faktor lainnya terkait penyakit diabetes mellitus (Elsous et al, 2017). 


\section{Hubungan antara Penggunaan Alternatif dengan Kepatuhan Berobat}

Analisis hubungan penggunaan obat alternatif dengan kepatuhan berobat didapatkan nilai $p$-value $=0,803$. Hasil penelitian ini menunjukkan bahwa tidak terdapat hubungan yang signifikan antara penggunaan obat alternatif dengan kepatuhan berobat pada pasien diabetes mellitus tipe 2 rawat jalan di RS Mardi Waluyo Kota Metro.

Hasil penelitian ini berbeda dengan hasil penelitian yang dilakukan oleh Bagonza et al (2015) yang menyatakan terdapat hubungan yang signifikan $(p$-value $<0,001)$ antara penggunaan obat alternatif dengan kepatuhan pasien diabetes. Dalam penelitian Bagonza et al (2015) disebutkan bahwa masih banyak pasien diabetes yang menggunakan obat tradisional terkait dengan mahalnya biaya pengobatan dan sering terjadi kondisi tidak tersedianya supply obat atau kekosongan stok obat di sarana kesehatan.

Keadaan ini berbeda dengan yang terjadi di Rumah Sakit Mardi Waluyo Kota Metro. Semua pasien dalam penelitian ini menggunakan fasilitas BPJS sehingga pasien tidak perlu membayar biaya berobat dan biaya konsultasi. Selain itu, stok obat diabetes di RS Mardi Waluyo Kota Metro tersedia dalam jumlah yang cukup sehingga hanya sedikit pasien diabetes yang menggunakan obat alternatif (37\%).

\section{Hubungan antara Edukasi Pengobatan DM dengan Kepatuhan Berobat}

Dari hasil analisis bivariat didapatkan bahwa tidak terdapat hubungan yang bermakna antara edukasi pengobatan terkait terapi diabetes dengan kepatuhan berobat pasien diabetes mellitus. Hasil penelitian ini berbeda dengan penelitian Bagonza et al (2015) yang menyatakan bahwa terdapat hubungan yang bermakna antara edukasi pengobatan yang diberikan dengan kepatuhan berobat pasien, di mana pemberian edukasi pengobatan dapat memperbaiki tingkat kepatuhan pasien.

Dalam pemberian obat pada pasien perlu suatu arahan dan petunjuk agar pasien mengerti jelas apa yang harus dilakukan pasien nanti dirumah sehingga lebih patuh dalam minum obatnya (Hannan, 2013). Perbedaan hasil penelitian ini dimungkinkan karena jumlah sampel yang lebih sedikit dibandingkan dengan penelitian sebelumnya.

\section{Faktor Dominan yang Berhubungan dengan Kepatuhan Berobat pada Pasien Diabetes Mellitus Tipe 2 Rawat Jalan}

Hasil analisis multivariat menunjukkan bahwa pasien DM Tipe 2 Rawat jalan dengan pendidikan dasar memiliki risiko tidak patuh sebesar 2,724 kali dibanding dengan pasien DM Tipe 2 Rawat jalan dengan pendidikan lanjutan. Selanjutnya, hasil analisis multivariat ini juga menunjukkan bahwa pasien dengan pendapatan $<$ Rp.2.100.000,- memiliki risiko tidak patuh sebesar 2,981 kali dibandingkan dengan pasien DM tipe 2 rawat jalan dengan pendapatan $\geq$ Rp.2.100.000,--.

Hasil analisis multivariat ini menunjukkan bahwa tingkat pendidikan dan pendapatan pasien merupakan faktor risiko terbesar yang berpengaruh terhadap kepatuhan berobat pasien diabetes mellitus tipe 2 di RS Mardi Waluyo Kota Metro. Hasil penelitian ini sejalan dengan beberapa penelitian sebelumnya. Hal ini dapat dipahami karena tingkat pendidikan seseorang sangat berpengaruh terhadap kemampuan dalam memahami penyakit dan pentingnya terapi pengobatan diabetes. Sedangkan pendapatan, sangat erat kaitannya dengan kemampuan pasien dari sisi pembiayaan terkait obat, transportasi, dan kebutuhan lainnya.

\section{SIMPULAN}

Sebagian besar pasien berjenis kelamin perempuan, berumur kurang dari 60 tahun, berpendidikan dasar, tidak bekerja, memiliki pendapatan kurang dari Rp.2.100.000,- dan berstatus menikah. Sebagian besar pasien memiliki penyakit penyerta, riwayat pengobatan lebih dari lima tahun, jenis obat yang digunakan adalah obat oral, tidak mengalami ROTD, tidak menggunakan obat alternatif, dan tidak diberikan edukasi terkait pengobatan diabetes.

Jenis kelamin, pendidikan, pekerjaan, dan pendapatan memiliki hubungan dengan kepatuhan berobat pada pasien diabetes mellitus tipe 2 rawat jalan di RS Mardi Waluyo Kota Metro. Pendapatan dan pendidikan merupakan faktor risiko terbesar bagi ketidakpatuhan berobat pada pasien diabetes mellitus tipe 2 di RS Mardi Waluyo Kota Metro. Pasien dengan pendapatan <Rp.2.100.000,- memiliki risiko tidak patuh sebesar 2,981 kali dibandingkan dengan pasien DM tipe 2 rawat jalan dengan pendapatan $\geq$ Rp.2.100.000,-. Pasien dengan pendidikan dasar memiliki risiko tidak patuh sebesar 2,724 kali dibanding pasien dengan pendidikan lanjutan. 


\section{DAFTAR PUSTAKA}

American Diabetes Association. (2017). Diabetes Care The Journal Of Clinical And Aplied Researh and Education: Standar of Medical Care In Diabetes. Vol.40.

Anna, M. (2011). Analsis Kepatuhan Penggunaan Obat Hipoglikemik Oral dan Pengaruhnya Terhadap Gula Darah Penderita Diabetes Melitus Tipe 2 Instalasi Rawat Jalan RSUD Dr. Moewardi Surakarta. (Skripsi. Universitas Muhammadiyah Surakarta).

Bagonza, James., Rutebemberwa, Elizeus., \& Bazeyo, William. (2015). Adherence to anti diabetic medication among patients with diabetes in eastern Uganda; a cross sectional study. BMC Health Service Research, 15, 1-7.

Boyoh, dkk. (2015). Hubungan Pengetahuan Dengan Kepatuhan Minum Obat Pada Pasien Diabetes Melitus Tipe 2 Di Poliklinik Endokrin Rumah Sakit Prof. Dr. R. D. Kandou Manado. Jurnal Keperawatan Fakultas Kedokteran Universitas Sam Ratulangi.

Elsous, Aymen et al. (2017). Medications Adherence and Associated Factors among Patiens with Type 2 Diabetes Mellitus in the Gaza Strip, Palestine. Frontiers in Edocrinology, 1-9.

Fatmawati, Sella Andani. (2017). Faktor-faktor yang Berpengaruh Terhadap Kepatuhan Minum Obat Pasien Diabetes Mellitus Tipe 2 di RSUD DR. Moewardi Periode Oktober 2016-Maret 2017. (Skripsi. Fakultas Farmasi Universitas Muhammadiyah).

Hannan, Mujib. (2013). Analisis Faktor yang Mempengaruhi Kepatuhan Minum Obat pada Pasien Diabetes Mellitus di Puskesmas Bluto Sumenep. Jurnal Kesehatan Wiraja Medika, 1-9.

Internatiobal Diabetes Federation (IDF). 2017. International Diabetes Federation Atlas. 10th edition.

Kassahun, Ashebir., Gashe, Fanta., Mulisa, Eshetu., \& Rike, Wote Amelo. (2016). Nonadherence andfaktors affecting adherence of diabeteic patients to antidiabetic complication in Assela General Hospital, Oroma Region, Ethiopia, Journal of Pharmacy \& BioAllied Sciences.

Morisky., Donald E, Ang., Alfonso, KrouselWood., Marie Ward., Harry J. (2008). Predctive validity of a Medication
Adherence Measure in an Outpatient Setting. Le Jacq. 5(10), 348-354.

Perkumpulan Endrokrinologi Indonesia (PERKENI). 2015. Konsensus Pengelola dan Pencegahan Diabetes Mellitus Tipe 2 Di Indonesia. Jakarta: 2015.

Putra, Okha Ferdiyan. (2013). Identifikasi Adverse Drug Reactions Penggunaan Obat Antidiabetes pada Penderita Diabetese Mellitus di Instalasi Rawat Inap RS " $X$ " Periode Februari-April 2013. Makalah Publikasi, Fakultas Farmasi Universitas Muhammadiyah Surakarta.

Romadona, A., (2011). Pengaruh Konseling Obat terhadap Kepatuhan Pasien Diabtese Mellitus Tipe 2 di Poliklinik Khusus RSUP Dr. Djamil Padang. (Tesis. Program Pasca Sarjana Universitas Andalas). Padang.

Serap, Taskaya \& Bayram, Sahin. (2015). Factors Influencing Adherence to Diabetes Medication in Turkey. Scholar Journal of Applied Medical Sciences (SJAMS), 3 (2A), 602-607.

Shams, Mohamed F.F., Barakat, Enaase A.M.E. (2010). Measuring the rate of theurapetic adherence among out patients with T2DM in Egypt. Saudi Pharmaceutical Journal, 226-234.

Santhanakrishnan, Iswarya \& Lakshminarayanan, Subitha. (2014). Factor affecting compliance to management of diabetes in Urban Health Center of a tertiary care teaching hospital of south India. Journal of Natural Science, Biology, and Medicine, 5(2), 365-368.

Soegondo, Pradana dan I. Subekti. 2009. Penatalaksanaan Diabetes Melittus Terpadu. Panduan Penatalaksanaan Diabetes Melittus bagi Dokter dan Edukator. Jakarta: Balai Penerbit FKUI.

Srikartika, Valentina Meta., Cahya, Annisa Dwi., \& Hardiati, Ratna Suci Wahyu. (2016). Analisis Faktor yang Mempengaruhi Kepatuhan Penggunaan Obat Pasien Diabetes Mellitus Tipe 2. Jurnal Manajemen dan Pelkayanan Farmasi, 2443-2946.

Suhadi. (2011). Analisis faktor-faktor yang mempengaruhi kepatuhan lansia dalam perawatan hipertensi pada di wilayah puskesmas srondol kota semarang. (Tesis, Fakultas Ilmu Keperawatan, Universitas Indonesia). Depok.

Tombokan V, AJM Rattu, dan Ch. R Tilaar. (2015). Faktor-Faktor Yang Berhubungan 
Dengan Kepatuhan Berobat Pasien Diabetes Mellitus Pada Praktek Dokter Keluarga Di Kota Tomohon. Jurnal Ilmu Kesehatan Masyarakat Unsrat, 2015. Vol.5. No.2 .

Wiffen, Philip., et al. (2015). Oxford Handbook of Clinical Pharmacy. England : Oxford University Press.
World Health Organization. 2013. The World Report: Shaping The Future.

Wulandari, Nora., Andrajati, Tetnosari., \& Supardi, Sudibyo. (2015). Faktor Risiko Umur Lansia terhadap Kejadian Reaksi Obat yang Tidak Dikehendaki pada Pasien Hipertensi, Diabetes, Dislipidemia di Tiga Puskesmas di Kota Depok. Jurnal Kefarmasian Indonesia, 6, 1-8. 